\title{
Reflections of Legal Culture in Television Comedy: Social Critique and Schadenfreude in the US Series "Frasier"
}

\author{
Stefan Machura ${ }^{1}$ (D) Olga Litvinova ${ }^{1}$
}

Published online: 11 July 2020

(c) The Author(s) 2020

\begin{abstract}
Traces of law can be found in all aspects of life, law is ubiquitous. People relate law to some of their most desperate life situations, and sometimes law serves them well. It is no wonder that law features prominently in popular comedies. There also is a tradition to ridicule authorities and social institutions, and the law, courts and legal professionals are no exemption. In order to be understandable and "funny", there needs to be at least a fleeting familiarity of the audience with them. Popular tv comedies thus offer a unique window into popular legal culture: they show elements of law and aspects of its workings, of the behaviour of lawyers, which the public relates to. For example, previous media coverage, other lawyer television and movies, or indeed personal experience, may have introduced them and something made this information stick, perhaps a rather objectionable practice. "Law" in this context has to be taken in its widest possible meaning as "living law" (Eugen Ehrlich), which means including those non-statutory rules by which society is organized, by which people live their daily lives. A further dimension which lends itself to good entertainment is rule-breaking behaviour, which often testifies for the validity of laws, only that they are inconvenient in certain situations. Again, a constellation that invites mockery, humour and Schadenfreude. The manuscript will apply a cultural and socio-legal perspective to the depiction of things legal in one of the most outstanding US television comedies, shown to audiences internationally: "Frasier" (1993-2004).
\end{abstract}

Keywords Popular legal culture $\cdot$ Law on television · Sitcom · Tv comedy · Frasier · American legal culture

Stefan Machura

s.machura@bangor.ac.uk

1 School of History, Philosophy and Social Sciences, Bangor University, Gwynedd LL57 2DG, UK 


\section{Introduction}

Traces of law can be found in all aspects of life, law is ubiquitous, as Talcott Parsons [43] put it. Law comes in different guises: limiting the choices people can make, but also safeguarding people's expectations of the behaviour of others [31], and thereby facilitating long chains of action. Many of these laws will sound like common sense and people usually follow them more or less automatically. In other instances, laws are the result of political and social struggle and may still evoke hostility in some quarters. People relate law to some of their most desperate life situations, and sometimes law serves them well. It is no wonder that law features prominently in popular culture $[4,19,20,33,36,42,54]$. There also is a tradition to ridicule authorities and social institutions, and the law, courts and legal professionals are no exemption. Indeed, the humorous portrayal of the law, of its arcane rituals, the solemn atmosphere of its institutions, and of the ways of its learned personnel forms a worthy object of study for scholars of popular legal culture. Tried and proven formulas of comedy and satire apply to the object of law: hopeless character flaws and awkward situational humour are only sharpened by the sense of importance and dignity surrounding the law. And then there is the ubiquitous fact of life that those with deeper pockets are able to avail themselves of more services, which of course eases their access to the law and more expensive lawyers. In American culture, lawyers have an ambivalent status, which lends itself to humour [17, pp. 609-610]. It is similar in other countries, but not on the same scale. The multiple functions of lawyers as "officers of the court" in the service of law, as representatives of their client's interest, as exponents of a proud profession, and as private entrepreneurs (or part of law firms), with an eye on the bottom line, provide contradictions, which spark incendiary laughter, but one that comes with an underlying feeling of horror.

In order for legal fiction to be understandable and "funny", there needs to be at least a fleeting familiarity of the audience with things legal. Popular television comedies thus offer a unique window into popular legal culture: they show elements of law and aspects of its workings, of the behaviour of lawyers, to which the public can relate. For example, previous media coverage, other lawyer television and movies, or indeed personal experience, may have introduced them and something made this information stick, perhaps a rather objectionable practice.

Scholars have started to look for legal culture in what might appear first as unlikely places, areas not worthy of study. This includes products of popular culture drawing on humour. For example, Robson [51] discusses the British strand of the "light legal procedural", offering lawyers and judges a medium to criticize courts and the profession. Podlas [47] emphasizes the assuring message of the American animated sitcom "The Simpsons" that law may work for citizens. Wolff [62] describes legal tv comedies in Japan and how they relate to the country's legal culture. Thus, turning to comedic portrayals of the law promises insights into how people perceive the law.

Sitcoms (situation comedies) are comic series defined by a family(-like) cast of main figures who show their character flaws in principally two key surroundings: a shared dwelling and a work space [22, pp. 111-112, 56, pp. 119-120]. 
It is here, where they engage with other, less central characters, some of whom may have their own side-lines. Sitcoms are produced for commercial reasons to regularly attract a wide audience [3, p. 19]. This requires that people understand, look through and often sympathise with the main characters. The travails of social climbers are a frequent topic of the genre [6, p. 123]. Transgressions against social norms are sanctioned through laughter, the audience is invited to judge the protagonists [6, p. 119]. As Bryant [6, p. 123] argues: Although sitcoms demand "a final return to stability, it is in the journey away from stability, the glimpsing of forbidden worlds of freedom, and the exploration but eventual repression of the wish to grow beyond one's prescribed role that we find the (...) dynamic appeal."

Figures may fail for being socially inapt, or for being out of tune with society. In the US sitcom ALF (1985-1990), for example, the furry extra-terrestrial living with the Tanner family took the unholy combination of egoism and consumerism to its most drastic extreme. The title figure of the series Ekel Alfred (Germany, 1973-1975) realised with angst that he had become a fossil from a more authoritarian past facing an age of-above all female-emancipation. Father Ted (UK, 1995-1998) struggled with the rigidities imposed on him by his choice of profession, the opening scenes not in vain showing a ship wrecked at a barren island. Situational comedies are one of the most versatile and most loved genres of popular culture. Their stories often invoke the realm of the law, the ultimate form of social norms.

Marc Galanter [17, p. 817], discussing public mistrust of the law, wrote about jokes:

"In different contexts, the same story may convey hostility, self-mockery, or grudging admiration. What people make of them varies greatly: lawyers and nonlawyers, men and women, educated and uneducated, rich and poor encounter very different bundles of jokes and may hear very different messages in a given joke."

It is different with popular television shows, especially comedies, as the producers driven by economic pressures and professional ambition, are anxious to appeal to the widest possible audience, so that insider humour does not come with a premium. Were they to cater to the tastes of one group only, e.g. lawyers, or the university educated, they would at minimum lose their prominent spot on the programme schedules. Popular comedy series tend to stick to the largest possible denominator. Moreover, through audience sympathy with characters, the story history and mise-en-scène, television comedies suggest a specific understanding and audience reaction. Producers have to achieve this to be successful in their trade. They have to aim at a general understanding of law-related situations.

Most people and certainly trained lawyers will think of law as formalised in legal text, set, laid out and enforced by appropriate state authority. The legal profession is to take centre stage in conflicts among citizens and between citizens and authorities. But "law" in the context of popular legal culture has also to be taken in its widest possible meaning as Eugen Ehrlich's "living law" [16], which means 
including those non-statutory rules by which society is organized, by which people live their daily lives. A further dimension lending itself to good entertainment is rule-breaking behaviour, which often testifies for the validity of laws, only that they are inconvenient in certain situations and any deviation needs to be covered up. Again, a constellation that invites mockery, humour and Schadenfreude. This text applies a cultural and socio-legal perspective to the depiction of things legal in one of the most outstanding US television comedies, shown to audiences internationally: Frasier (1993-2004).

\section{The Frasier Habitat}

For 264 episodes in eleven seasons, the sitcom Frasier about the travails of a psychiatrist-turned radio personality, entertained American audiences on NBC. It continues to be watched internationally on repeat scheduling, on pay tv, and lives on with the help of DVD sets and fan websites. A sequel is possible [21]. Frasier and the people behind this remarkable success have collected many prizes, including 37 Emmy wins [10, p. xi]. The actor in the title role, Kelsey Grammer, received the highest critical praise for his performance, as did the writing team of the series. Frasier must have some of the funniest moments of tv history, but there are dark topics and sad moments, too. The quality of acting is superb as evidenced already in the earliest episodes when Grammer and Peri Gilpin as "Roz" react to the utterances of the other as if not just reciting a script, but relishing the banter in the very moment of acting.

Frasier follows the tried and proven concept of a "traditional sitcom" in which "a group of characters who share a residence or workplace stumble into various comical situations" [42, p. 18]. The series borrows its lead character from the forerunner comedy Cheers (1982-1993), where the figure of Frasier developed into a main stay [10, pp. 8-12]. Dr Frasier Crane is an ardent admirer of Sigmund Freud, an intellectual art lover, an avid consumer of luxury goods, and a "pompous but needy romantic" [10, p. 11]. The doctor has a deeply insecure personality; and could use psychiatric advice himself, especially when it comes to matters of love, marriage and family life. Frasier is never quite happy for long, and if he were to answer his father's perennial question "Why can't you be happy?", Daniel J. Morrissey [41, p. 415] suggests he could answer:

[T]hat his life represents the best that post-modernism has to offer: either a this-is-as-good-as-it-gets materialism or, from another perspective, the triumph of style in a world lacking any real substance.

By the time the series Frasier sets in, the title figure has separated from his wife Lilith (a psychiatrist herself) and rarely sees her and their son. Lilith's cool and calculating character is very well characterised by her not allowing her son to play with other children, but to observe their play and take field notes.

In Frasier, the audience is not only offered the occasional contrast between the warm and insecure personae of Frasier and the cold and confident Lilith, but the series writers doubled the Frasier character by introducing his psychiatrist younger 
brother Niles who shares many of Frasier's flaws. The two are intimately connected by fierce sibling rivalry. Niles takes some of Frasier's traits to the absolute extreme and combines them with insane phobias. Together they share a yearning for acceptance in high society, the love of exquisite vine, food and the art, of European luxury goods, and a troubled relation with women. For the most part, Niles is able to realize his ambitions in the sphere of consumption through a marriage and finally a lucky divorce from a multimillionaire wife. Frasier's expensive lifestyle is financed somewhat unexplained through his work as radio therapist. They do not come from money, as their father, Martin Crane, was a humble police officer and their long deceased mother a forensic psychiatrist. However, she has left the two Crane boys with loads of cultural ambition and the wish to belong to the finest circles of society. In other words, "the heart of the series is the Cranes' intrafamily culture clash, the kind that's bound to occur when blue-collar Americans send their children to Harvard" [18].

When the Frasier series sets in, Frasier is forced to take his disabled father into his apartment. The down-to-earth, if not occasionally vulgar tastes and behaviours of the father and the different ways of his sons clash throughout the Frasier story. The constellation provides for an endless number of jokes playing on the class difference. Where father Martin relishes his can of beer, Niles orders in a café: "Double cappucino, half-caf, non-fat milk, with enough foam to be aesthetically pleasing, but not so much that it would leave a mustache" [46, p. 40].

Gary Hoppenstadt, commenting on the predecessor series Cheers, illustrates the point:

"The show fundamentally satirizes social class in a very effective way, establishing humorous contrasts (which makes for great comedy) between the jock (and the common laborer) with the intellectual, the highbrow with the lowbrow, having both groups portrayed as unable (or unwilling) to fully understand each other's worldview or social culture (which, again, makes for great comedy). It is the humorous 'clash of cultures' and their subsequent attempts at social integration which is fundamentally American in nature and thus appealing to an American television audience.'[10, p. 7].

The camp of the "commoners" in Frasier also comprises two female main characters: Roz and Daphne. Roz Doyle is the producer of Frasier's call-in radio show and apart from being very impulsive and changing male partners constantly, deeply rooted in rural American culture. Though her mother is a state attorney, and thus holds high legal office, Roz is the proverbial "all-American girl". Daphne Moon (played by Jane Leeves), Martin's home health care worker, instead, hails from a dysfunctional family in Manchester (UK). Apart from these characters, there are many more with memorable appearances and if a main fault line exists, it must be class and the cultural rift going with it.

In the final analysis, the viewer is prompted to laugh more about the rich and "cultured" than about the commoner. In the episode Door Jam Frasier and Niles get access to a highly exclusive private spa club through false pretence. At first, they are happy about the insane ways in which they are indulged. Only, when they see 
a US Senator go through a golden door into a separate, even more selective part of the spa, and hear it is not for them, they absolutely need to get into that one, too, and all that has impressed them before, is worth nothing now. They eventually are in the more selective area, but while being treated there, they detect a further, a platinum, door. Having been told that they won't have access, Frasier and Martin sneak through, "this is where we belong" [44], only to find themselves in the backyard, surrounded by garbage bins and-locked out. Drawing on Lorenz's [30, p. 74] analysis of humour as involving the three elements feelings of superiority, misunderstandings and an uncomfortable subject, the Frasier episode draws on viewers looking down on the misguided brothers, their misinterpretation of the situation, and the subject of unbound consumerism. Social critique in "Frasier" is unmistakably directed against the higher classes mainly and it offers viewers the immense pleasure of proper Schadenfreude.

\section{The Weird and Wonderful Sphere of Sub-state Law}

Eugen Ehrlich, one of the founding fathers of socio-legal studies, is best known for his theory of the "living law", more precisely, of those rules by which associations in society organise the life of their members [16]. In the remote Bukovina province of the Austro-Hungarian Empire, he described how professions and local groups regulated themselves, without the help of codified law [15]. The emphasis on the intermediate level of society was shared by Ehrlich's contemporary Emil Durkheim. Only that Durkheim aimed at a level a bit higher and more formally organized. The French pioneer of sociology saw in professional associations a better form of democracy, an alternative to what he criticised as destructive centralised state politics [14]. As much as there is something wonderful to aspire to in grass-roots organisations, in mutual self-help, cooperative effort, strong neighbourly relations and even professional structures (maybe), popular culture also always knew of its potentially weird downsides. Sticklers for perfection, for example, turn their devastating efforts to creating association rules. Others read statutes to their advantage and utilise them mercilessly against opponents, or run their club like a family business. If an opportunity emerges that is too good to let it pass, even true believers are tempted to stray from the code of ethics.

In Frasier, the law of associations and their slippery social and ethical terrain appears in three settings mainly. Several episodes see Frasier engaging in the politics of the condominium, trying to utilize its power against his neighbours. The vine tasting society allows Frasier and his brother Niles to compete recklessly. Finally, the ethics code of the psychiatric profession frustrates some of Frasier's most personal urges.

Owning an apartment in a luxury condominium, Frasier takes a keen interest in defending his parking space and his view of Seattle, as well as in holding the top position on the condominium board. The latter goes so far that he puts forward his father Martin Crane as an additional candidate for board president when he realises, he himself is not too popular, pressuring Martin to accept becoming his puppet. With a rhetoric reminding the film connoisseur of speeches in Hollywood dramas like 
Amistad (USA 1997) or, rather, in The Man Who Shot Liberty Valence (USA 1962), Frasier fights in the condominium assembly against a neighbour. The man had parked his Humvee SUV on Frasier's parking space and in reprisal against Frasier's complaint fixed a giant stars and stripes flag at the building, covering Frasier's panoramic balcony view. In a speech seeping of patriotic tropes, Frasier succeeds with the proposal to better have such a giant flag on top of the building, having to fork out personally for the installation.

Frasier and Niles frequently exercise their vine tasting buds and play word games describing the qualities and origin of vine. Little do they know that the vine tasting society's annual election of the "cork master" is about to take their rivalry to a head. Just when Niles starts to make his acceptance speech as new "cork master", Frasier interrupts and fires a salvo of motions, only to declare that he quits the club. Frasier tells about a new radio show he will run on vine and that he cannot do both, the show and be a club member. In his new show, Frasier waits for callers from the vine club in vain as Niles has instructed them not to participate, based on his interpretation of the club statutes. When Frasier confronts Niles in a club meeting, Niles has him escorted out of the room. Father Martin finally intervenes, and Frasier is back in the club. Afterwards, Frasier and Niles start talking:

Frasier: So what's preventing us from starting a whole new club from scratch?

Niles: We could really get back to basics!

Frasier: Something that's just about vine! And a clear constitutional procedure for enjoying it!

Niles: Yes, only maybe this time the governing body could be bicameral!

Frasier: Well, I don't know, Niles, there is something to be said for the parliamentary system!

Niles: Well, either way we have to have a strong judiciary to keep it in check.

Frasier: God, I love vine. [28]

Twice divorced and once left at the altar, Frasier Crane is unable to form lasting relations with women and even finds approaching women difficult. The more he is thrown into a dilemma when it comes to the basic professional ethics that psychiatrists won't have relations with their clients. In an even wilder twist, Frasier suggests a caller in on his radio advice show to better split from his partner, only to then finding himself attracted to the same woman. Where Frasier ultimately stops when realizing the conflict, the psychiatrist of Niles's wife, even starts an affair with his client.

Frasier and Niles know that their social existence is intrinsically connected to the rules of the associations they belong to. Yet, taking advantage of what civil society offers, comes at a price. To successfully negotiate the treacherous cliffs of association life, they are thrown back on their own devices, much as the viewers are. This changes in the area of civil law that is more closely connected to the rule of the state-and the rule of the legal profession. 


\section{Civil Law and Lawyers}

The civil law governs most of the legal relations people have. In legal theory, it is the law in which all affected are equal, unlike public law, including criminal law, where the citizen is confronted with the state as superior authority. But there is a nagging suspicion that not everyone is equal in practice.

Civil law allows private parties to create law that will direct their actions and that is enforceable in a court of law. Typically, this is the world of contractual relations and labour law is not different. In "Frasier", agent Bibi masters the art of manipulation, to make her client artists and broadcasters agree to suggested deals. No ruse is too amoral for Bibi and she preys on Frasier's vulnerabilities. In exchange for the hope to become a bigger star, Frasier allows Bibi to deduct a sizeable cut from his income.

Law can be created with good intentions, but has a dynamic of its own, not always welcome, or has been introduced in the legal code before there was a widespread acceptance of its content. By the end of the penultimate season, Roz accepts a job as manager with another broadcaster, only to in the first episode of the eleventh season, tell Frasier about quitting it. In part, because "my assistant is an idiot and I can't fire her 'cause she's like three minorities rolled into one." [9] Some viewers may feel for Roz on this occasion, others may laugh about Roz's naiveté.

Otherwise, in "Frasier", civil law appears most prominently in connection with lawyers, and more specifically-probably owned to the adult family sitcom genre-when it comes to divorce. The harsh reality is that wealthier parties to a dispute may be able to buy superior legal services [2, pp. 272-275, 61, p. 892]. Going down the legal route tends to aggravate a dispute, entrenches parties' positions and can bring about the worst in people. Such constellations allow for endless grim humour as the protagonist's most private feelings are at stake and ultimately their status in society mocked as well. Will they be fooled by the opposing party, tricked by their opponent's expensive legal representatives, or even exploited by their own lawyers?

But first, there is the litigation angst to be discussed. The United States have a prominent debate around alleged extreme litigiousness of its citizens. People are perceived to sue another too quickly, especially if the other side has deep pockets [17, pp. 828-829, 59]. For David Ray Papke [42, p. 20], the popularity of law in American fiction exemplifies that it is the "most legalistic" culture "in the world". The issue reappears in "Frasier" to good comic effect. For example, in the last series, Roz tries to set Frasier up with a non-too-attractive friend of hers: Anne, working in the claims department of an insurance company. Frasier rejects her in a way that leaves hurt feelings. Some time later, Frasier finds out that his apartment is uninsured as his father forgot to take the payment cheque to the mail. In desperation, he invites Anne to his house to discuss setting up an insurance, although aware of the pre-history between the two. Anne visits harbouring high hopes but slips in the kitchen and breaks her leg. Frasier panics at the thought of having no insurance, and Anne knowing how to sue for damages. 
He may be losing all his prized possessions to pay for medical expenses and compensation. So he hedges the plan to host Anne in his apartment while she recovers as "friends do not sue each other". Following genre conventions, this goes spectacularly wrong, as Anne feels betrayed again. It is only after several twists and turns, that Frasier gets her to sign a document in which she forfeits her rights to sue-with three copies, to be absolutely sure.

Having reviewed the spectrum of American lawyer films, Michael Asimow [1] writes that people connect lawyers with some of life's worst moments. He states that the portrayal of lawyers is mainly negative, he would not want them as friends due to their bad character and more often than not, they are unethical professionally. Not surprisingly, the comedy Frasier draws a similar picture and disregards for the most part the other, the heroic side of lawyers which is so prominent in classics like Young Mr Lincoln (USA 1939) [5] and contemporary lawyer tv series like The Good Wife (USA 2009-2016) [37].

Lawyers can be expensive. In one of his adventures, Frasier is in love with his good-looking sharp female lawyer, but when he receives the bill for her legal services, he is so outraged that his reaction ends their relation. Niles separates painfully from his wife Maris and the legal expenses get so high that he who otherwise only eats gourmet food and dines in elite restaurants is temporarily reduced to a meagre diet of sandwiches. It becomes increasingly obvious that he is losing out. His desperation becomes most obvious in the following scene in Frasier's lounge in presence of his father Martin and Daphne:

Daphne opens the door to Niles, who's on his cell phone.

Niles: (into phone) Good God, man, whose lawyer are you, anyway? No, I will not calm down. (To Daphne: (calmly)) Hello, Daphne (On phone) They call that a settlement? Call them and turn it down. (Louder, over TV) I said turn it down, you ninny!

Martin: (Turning down the TV) Okay! Geez, you could ask a person nicely.

Niles: (Hanging up) I have got to find a new divorce lawyer. Claude is clearly no match for Maris' team.

Daphne: Real sharks, are they?

Niles: When I was courting Maris I sent her a Valentine that read 'You're the girl my heart adores. Everything I have is yours.' Now they insist it's a prenup. Daphne: That's terrible. (To Martin) Can you imagine using that as a weapon - a Valentine? [24, pp. 256-257]

The scene hints at the secret affection Niles and Daphne developed for another. What follows is a twist on the familiar plot pattern of "The lawyer gets the girl" [11]. Looking for a new champion of his legal case, Niles is introduced to the city's top divorce lawyer, Donny. The man has a phenomenal reputation and he turns out to be completely shameless, up to the point of changing his clothes in presence of his clients. Nevertheless, once tasked with the job, Donny takes the case to a swift resolution and even a favourable one for Niles. Though, in the end, Niles will suffer a loss elsewhere.

In legal drama and comedy, lawyer heroes like Young Mr Lincoln often solve their case not by legal means but through common sense and general social 
competence. Donny surprises Niles with a question, if he knew where the money of Maris's family, occupying high social status in Seattle, comes from? Obviously, Maris never told Niles nor anybody for fear of becoming a laughing stock sneered upon by the fine society. They made a fortune out of selling urinal cakes! Donny prompts Niles to make a phone call, and Maris immediately agrees to silence him with a generous settlement-But Niles cannot celebrate his victory for long, as tragically, Donny sweeps away his beloved Daphne. Only many eventful episodes later, Daphne decides to elope with Niles at her wedding to Donny.

\section{Crime and Criminal Law}

Norm violations, the apportioning of blame to individuals and generally inviting moral judgment are some of the tried and proven recipes to attract audiences, be it for news [32], or be it for legal fiction [35]. The breaking of law [45], especially criminal law [40], triggers an emotional response. People fear that the stability of society is at stake and observe if the rules are upheld and the perpetrators punished. Once they perceive this to happen, the general social cohesion is strengthened [13]. These basic social reactions are also at work when it comes to the audience's interest in crime news and crime fiction [35]. Comedies often also draw on crime, the detection of crime and the sanctioning that follows, only that the real hurt caused by crime is taken out of the equation largely. Already the earliest forms of crime fiction have preyed on another response to crime additionally. As much as people like to see perpetrators punished, there also is a certain fascination by the gallant robber, the Robin Hood-imposter, who brazenly takes from the rich and powerful, and gets away as well. In crime fiction, these figures make good entertainment and in comedy, crime and punishment are not only not taken seriously, but laughter is created by exposing character weaknesses and temporarily reversing the mundane social order.

A large number of Frasier episodes features some aspect of crime. Most of it is rather trivial, but there also is the arrest of Niles' first wife Maris for killing her abusive lover. Niles had inadvertently provided the murder weapon: an ancient crossbow which Maris claims to have fired in self-defence, having asked Niles before to lend it for a theatre performance. The Frasier characters can be found as victims as well as perpetrators. In a particularly poignant story, Frasier and Niles want to get to a festival in the Seattle park in honour of the popular radio psychiatrist. All goes wrong, they make hardly any progress on the way to the event. When Frasier decides to take a shortcut through a backstreet, they are promptly robbed of all their possessions, money and phones. In desperation, wanting to use a public phone, they steel a coin from a blind street musician and have to outrun schoolchildren trying to apprehend them. This and other episodes, such as when Niles and Frasier buy insane amounts of caviar from Russian smugglers, suggest that depending on circumstance everyone may commit illicit acts and find themselves at the wrong side of the law. The response of the audience can best be described as Schadenfreude, again.

Criminology has long questioned Cesare Lombroso's and others' theory that "criminals" can be recognized by their bodily features [8, pp. 87-90, 95-96, 29]. 
But some of the belief in the recognisability of character traits and the idea that loose women, crooks and unworthy people give away secret signs, which so prevailed in the nineteenth century [53], is still around in popular culture today. Moreover, the crime genre of the whodunit fascinates audiences by inviting them to guess who the perpetrator was [49]. The Frasier episode You Can't Tell A Crook by His Cover mocks these ideas. Martin has invited his "poker pals" from the precinct over for a game. He challenges Frasier who had boasted with his Harvard degree in "Psychosocial Behaviourism", to a bet that he won't be able to tell who the police officers are, and who is an "ex-con". Frasier spends the evening intensely studying the poker players, until the group breaks up.

Martin: Well, I guess there's only one thing left. How about it, Fras? You figured it out yet?

Frasier: Actually, I believe I have. Shall we step into the drawing room? Please have a seat.

Martin: Okay, Sherlock. You've got center stage.

Frasier: I have sketched an accurate psychological profile of each one of you. And in so doing I have come to the incontrovertible conclusion that the criminal among us can only be... FRANK!

Martin: Wrong. Frank's a highly decorated undercover cop.

Frasier: Exactly! Just a little too obvious, you know. The broken vocabulary, the jailhouse pallor, the underdeveloped social skills...

Frank: Hey.

Frasier: [to Martin] So, you tried to use psychology against me, did you? Threw a gender bender at me. Thinking I'd just assume that a felon would naturally be a man. Well, I'm on to your little game, mister. The criminal among us is indeed, the very wily Linda!

Linda: Nope.

Frasier: JIMMY!

Martin: Hey. You're right.

Frasier: Damn it... you seem like such a nice guy. [26]

To add insult to injury, Jimmy had used the opportunity to ask out Daphne for a date in the ill reputed "Topaz Room" bar, and Frasier and Niles have to rescue her.

That not all is as it seems becomes more obvious in the portrayal of the police, where father Martin shows once more the darker side of his character.

\section{Portrayal of Police}

On balance, the police gets a good treatment in Frasier, as for example in "reality tv" shows in which the camera follows police officers $[38,50]$. Officers for the most part appear upright and conduct their duties in a competent manner. They provide a "normal" counterpart to the crazy behaviour and norm violations of the Frasier brothers which they are obliged to reign in from time to time.

The adventures of Frasier and Niles lead them to occasionally stray from the straight and narrow, when for example Frasier takes a U-turn on the highway, or 
when Niles tries to steal a street name sign to impress Daphne. With his past as a police officer in Seattle, who was wounded while on duty, Martin still has contacts in the force and he uses them, e.g. if he has to get Frasier or Daphne out of police arrest. Martin also knows how to distract border posts from finding out that Daphne crossed the US boarders without proper paperwork. He aggressively interrogates Niles and Daphne's housekeeper suspected of stealing-but ultimately, the chance discovery of a videotape reveals that it was Daphne's own mother who took things out of the household. When Frasier admonishes Martin for stereotyping people, Martin is not really getting the message: not even when it is positive? "[T]he policeman discriminates in his behaviour", as officers look out for people and situations [25, p. 184]. Not only the US audience will be aware of accusations that the police is biased against e.g. black citizens or ethnic minorities [58]. Through his portrayal in "Frasier", the figure of Martin becomes a symbol, signifying what is good and bad in US police.

Martin Crane was shot by robber David Hicks, survived, but the hip injury forced him to quit his beloved career. His cane, the massage sessions, and his pains remind him daily of the crime. In the episode A Day in May, he attends, as every year, the hearing given by the parole board to Hicks. As is now a familiar ritual, Hick's mother Joanne is present hoping for the release of her son.

"1st BM [board member]: Can you tell us what consideration, if any, you've given this crime?

David: Well... I regret it, every day. I was young at the time, and I wasn't thinking - you know, about the consequences. And I'm very sorry.

2nd BM: The victim is here. Mr. Crane? [Martin stands up] Would you like to make a statement?

Martin looks at Joanne, then shakes his head.

Martin: I have nothing to say. [sits back down]

3rd BM: Would you give us a moment?

The Board confers with each other in whispers.

3rd BM: Mr. Hicks, the board commends you for your participation in the inhouse programs to better yourself, and for your record of excellent conduct. We have weighed this against your conviction of shooting a police officer during the commission of a robbery - and find that the length of your time served has not yet met the standards for proportionality, equality, and justice as required by state law. Parole is denied.

As the Parole Board gets up and leaves the room, the guard comes forward to take David back to his cell. Joanne begins to cry, softly. Martin rises, considering whether or not to say anything to her - and then decides to leave quietly." [63]

The audience is led to the conclusion that ultimately, David's fate lies in the hands of Martin. If only he could find it in himself to, not even forgive, but to accept the man's efforts to become a better person, the parole board will find for David. Martin is aware of the mother's torment, but his own feelings are more important to him. The parole board's announcement cites common principles of justice [12], but they rather sound empty, fig-leaves covering up how the decision has been made [58]. 
Often, sitcoms send "the message of what is right through the characters often doing what is wrong" [30, p. 81]. This scene is a rare example within the corpus of popular crime fiction to depict a parole board and such a moral dilemma.

Martin is the toughest character in "Frasier". Some of his behaviour reminds audiences of portrayals of the police and news stories showing the cops in a less than flattering light, abusing their power for private reasons. The old man never liked both of his son's wives, Lilith and Maris. In the episode "The Return of Martin Crane", Martin confesses to a fellow police officer that he booted the car of Maris after persuading four men to help him moving it in front of a fire hydrant.

\section{Courting Court Tv}

Courts and judges hardly appear in Frasier. In one episode, a public prosecutor is present in a neighbour's apartment, who cannot stop investigating people, right when Frasier had stolen a 1936 Olympic medal under the influence of acute sexual frustration. When Niles and Daphne want to have a repeat marriage ceremony for their family, after they had a quick one in Reno before, two patient judges, one male, one female, one black, one Asian, suffer the chaos they create.

In Frasier, there is, however a clever story around an appearance of the Crane brothers on court tv, exemplifying the entertaining value of self-reference of media [39]. Many products of popular legal culture refer back to previous films or shows. The audience enjoys recognising the relation, reading the current portrayal in context with their past experience.

The episode "Crane vs. Crane" deals with the brother's rivalry, each of them supporting another side in a legal case. The Internet Movie Database [23] aptly summarizes the plot as follows:

Niles eagerly agrees to appear as an expert witness at the capacity hearing of an elderly timber baron, knowing that the proceedings will be televised. The man approaches Frasier for a second opinion. Frasier agrees to meet with the man, and finds him perfectly sane, leaving him no choice but to testify against Niles in court.

Tellingly, a subheading of the script reads: "Another reason to keep cameras out of the courtroom" [27, p. 6]. The writer is the same as for the episode You Can't Tell A Crook by His Cover. David Lloyd according to the New York Times was "legendary among Hollywood script writers" [60]. Again, he touches on a topic that is debated in legal and academic circles. Especially after the O. J. Simpson case was televised, court tv appeared to many as a source of negative influence ("When the law goes pop": [55]). Critics did not fail to point out that litigants, lawyers and witnesses may be distracted from the trial and play to the camera. One observer even commented that in the O.J. Simpson case: "No one enjoyed the attention more than the judge" [57, p. 249]. Niles and Frasier, in their never-ending sibling rivalry, become victims of the lure of fame through court tv. As Frasier rises to address the judge, Niles-determined to have his "day in court"-moves forward and backward on his seat to be in full view of 

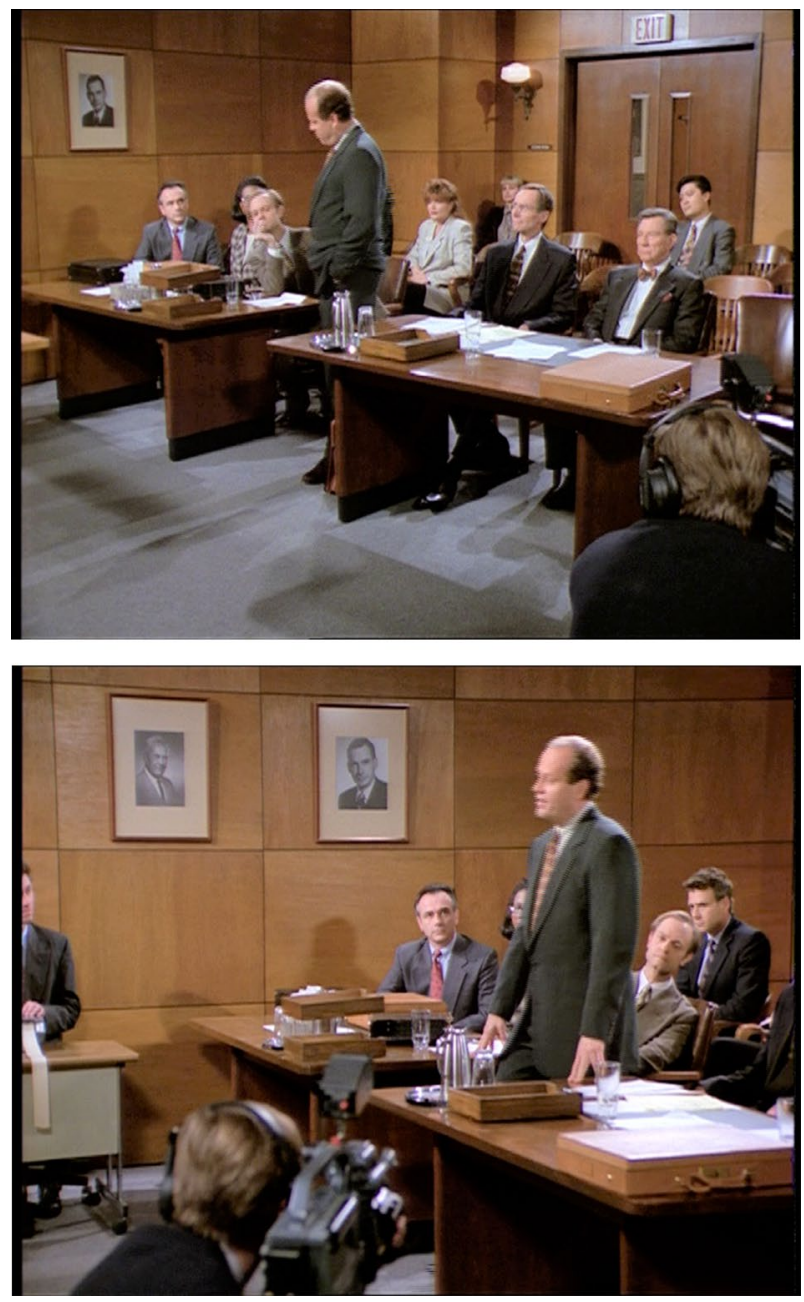

Fig. 1 Frasier (Kelsey Grammer, standing) addressing the judge and Niles (David Hyde Pierce) shifting behind him, eager to be seen on court tv. Stills from "Frasier", episode "Crane vs. Crane"

the camera (Fig. 1). Only, just as Frasier delivers his expert evidence in carefully chosen words, declaring the timber baron as perfectly sane, the old man starts to act weirder and weirder, leaving the court no option but to find against him. This early termination of the trial prevents Niles from any talking part. In his frustration, Niles stays behind when everyone vacates the courtroom and delivers his speech first to Frasier, sitting down in the judge's chair. When Frasier soon disappears, Niles pays the bailiff to listen. 


\section{Taking Justice into One's Own Hands}

Not only the court tv episode exemplifies the clever use of the pop cultural memory. Another example for self-reference of law fiction is in the episode High Crane Drifter. The title alludes to the Clint Eastwood classic High Plains Drifter (USA 1973). In this Western, one day, a stranger without name arrives in a completely corrupt town, which was complicit in the murder of its marshall. Now he is persuaded by the inhabitants to defend it against bandits. The lone rider metes out his version of "justice" which includes raping a towns woman [52, p. 2]. High Planes Drifter thus is no film to simply enjoy and ultimately tells a cautionary tale.

In the Frasier episode, the protagonist suffers from a series of rude and uncivil behaviours, until he finally snaps and manhandles a Mr. Harvey out of Café Nervoso, who jumped the queue to snatch a table. The next morning, a local paper brings the headline The Crane Mutiny. (In itself a pun at the novel-turned-film The Caine Mutiny, USA 1954, in which lieutenants relieve their captain of his command to save the ship and consequentially face a court-martial.) The article eulogizes "Three cheers for Dr. Frasier Crane, who struck a blow against rudeness yesterday in a coffeehouse melee." Finally, Martin has a reason to be proud of his son. On his way to work Frasier is celebrated as a hero by people on the street and colleagues applaud him in the station. Helle Porsdam's [48] interpretation of the popularity of tv judge shows like The Peoples' Court (USA 1981-1989) comes to mind: Americans loved to see the lines between licit and illicit behaviour be drawn by the authority figure of the tv judge Wapner. The same audience fascination exists for the Western hero or police officer putting things right, and reminds sociologists of law of Durkheim's theory of social cohesion [35]. In any consequential comedy, such a moment of triumph is bound to be short. Frasier's mood soon changes as one caller after the other boasts about more and more extreme forms of revenge they took to pay back their fellow (wo)man. While on air, Frasier starts to regret his use of force in the café: "[W]ho am I to draw the line at the acceptable use of force?" [7] Back in the café, Frasier encounters the same man as the day before, Mr. Harvey, and his apology and acceptance of "full responsibility" gives Harvey the chance to announce suing Fraser. In a sudden twist, which plays on the audience's awareness of American litigiousness, Niles comes to the rescue:

Words cannot do this justice - you have to see it. Mr. Harvey lightly pokes Niles on the shoulder. Niles acts as if he were punched. He begins reeling backward - laying waste to chairs and the coat hanger - finally landing atop a table and sending it and he crashing to the floor. The entire café gapes at the scene as Frasier rushes to his aid.

Frasier: Niles!! Niles... are you all right?!

Niles: [pulling Frasier close to him and whispering] Counter suit!

Frasier: [jumping up] Oh, my god!! Nobody move him!

Harvey: I barely touched him!

Frasier: Then you admit you touched him! [to crowd] He admits it! [Niles groans] Oh, Niles. Niles, I'm here for you. I promise we're going to get you 
the best care that THIS MAN'S MONEY CAN BUY! [out of earshot] My

god, Niles, that was brilliant. You even got a tear in your eye!

Niles: I landed on a fork." [7]

Again, a Frasier episode uses the rich cultural reservoir of crime stories to good effect. For all the stages of Frazier's feelings, wanting to defend what is right, enjoying the accolade, rueful at having set a bad example, and turning the table against someone threatening to mobilize the law against him, there are plenty of examples in popular culture and the creators of the series can be confident that their audience will be able to follow and enjoy the adventure.

\section{Conclusion: Popular Legal Culture in Popular Comedy}

The critically acclaimed series Frasier examplifies how comedies deal with topics of law, crime and justice in a grotesque and poignant way. Still today, the sitcom is internationally popular, and most of its law-related content will be understandable to audiences beyond the United States. Some situations may be more poignant to a US audience, though. For example, lawyers have an ambivalent status in American popular culture: as they are often handed positions of leadership, while on the other lawyers are famed for the toll they take on parties involved in disputes. American popular culture also celebrated the individual hero dispensing justice more than films, television or novels in other countries. The western provided the paradigm.

Nevertheless, international viewers will be familiar enough with American stories to read them. American patterns of telling have deeply influenced film and tv producers elsewhere [39]. In addition, people tend to share similar basic principles of justice. They can thus understand "foreign" stories, especially when it comes to fair or unfair treatment of people by legal authorities [34]. Moreover, as demonstrated in the scene dialogues quoted in this article, short snippets are enough to remind the audience of the intended meaning. The smallest of signs can be used to invoke the cultural repertoire. Naming an episode High Crane Drifter reminds cinema-goers of a controversial Western and sets them up for an intertextual reading of the Frasier episode. Displaying the words "Another reason to keep cameras out of the courtroom" connects another episode with a general discussion and recent events around televised court trials. Those signs are like keys opening access to the golden door of popular culture and the platinum door to the gritty world of legal, social, political conflict.

The series Frasier and similar comedies tell scholars of popular legal culture which aspects of the law, its institutions and personnel are so widely known that they are used beyond the narrower law-related genres. The study of these contents indicates what can be safely assumed to be an understanding shared by a widest possible spectrum of society. Television shows like Frasier would not work if they did not appeal to fears, hopes, ambitions, expectation of all sorts, even prejudice, harboured by the audience.

Many of the issues touched upon by Frasier are universal. Even where they relate to private aspects of life, the law has an impact too. Divorce, its treatment in law 
and by legal actors is the prime example in the series. The horrors that come with it, and the dark humour they allow for, will be immediately understandable. Countless areas of civic life have a legal side to them, especially if sub-state law is taken into the equation. While law enables us to enter into and enjoy social relations, it also becomes a formidable force in the hands of opponents. Frasier capitalizes on conflicts between neighbours, at the workplace, in associations and between the state and its officials and the individual. The sitcom feeds on sometimes miniscule nuances to everyday situations, on mishaps and misunderstandings, which, occasionally aided by ill will, turn into stressful challenges for the protagonists.

This works as comedy because the audience sympathises with the characters of Frasier and his extended family, neighbours and colleagues. Viewers are able to grasp their motives, (almost) none of them is so repulsive as to not allow the operation. Take the main protagonist: hardly any living person will resemble Frasier, but an audience will be able to recognise aspects of his character in people they know, his insecurities and occasionally childish behaviour as well as his wish to have positive relations to others. Some of them the audience may even share with Frasier, making them feel for him even more. In the final analysis, what the law does to Frasier and what Frasier does with the law, might potentially be what happens to them.

The law cannot shake off a basic ambiguity: In as much as it should be an instrument to serve people's needs, to benefit society, an expression of social values, it encounters people as a constraining force, sometimes a tool in the hands of the powerful, often leaving them vulnerable to the choices of legal professionals. In 264 episodes over 11 years, Frasier and his companions had their fair share of the law, taking a sympathetic audience with them on their journey.

Funding Not applicable.

\section{Compliance with Ethical Standards}

Conflict of interest Not applicable.

Open Access This article is licensed under a Creative Commons Attribution 4.0 International License, which permits use, sharing, adaptation, distribution and reproduction in any medium or format, as long as you give appropriate credit to the original author(s) and the source, provide a link to the Creative Commons licence, and indicate if changes were made. The images or other third party material in this article are included in the article's Creative Commons licence, unless indicated otherwise in a credit line to the material. If material is not included in the article's Creative Commons licence and your intended use is not permitted by statutory regulation or exceeds the permitted use, you will need to obtain permission directly from the copyright holder. To view a copy of this licence, visit http://creativecommons.org/licen ses/by/4.0/.

\section{References}

1. Asimow, Michael. 2000. Bad lawyers in the movies. Nova Law Review 24: 533-591.

2. Asimow, Michael, and Shannon Mader. 2013. Law and popular culture, 2nd ed. New York: Lang.

3. Badanjak, Sascha. 2005. Sitcoms, soaps und drama series. Medienheft Dossier 23: 13-19. 
4. Bergman, Paul, and Michael Asimow. 1996. Reel justice. The courtroom goes to the movies. Kansas City: Andrews and McMeel.

5. Böhnke, Michael. 2001. Myth and law in the films of John Ford. In Law and film, ed. Stefan Machura and Peter Robson, 47-63. Oxford: Blackwell.

6. Bryant, John. 1989. Situation comedy of the sixties: The evolution of a popular genre. Studies in American Humour. New Series 2(7): 118-139.

7. Burditt, Jack. 1996. High crane drifter (transcribed by Andrea Day). KACL 780.net. http://www. kac1780.net/frasier/transcripts/season_3/episode_17/high_crane_drifter.html. Accessed 19 August 2019.

8. Burke, Roger Hopkins. 2019. An introduction to criminological theory. 5th ed. London: Routledge.

9. Daily, Bob. 2003. No sex please, we're skittish (transcribed by David Langley). KACL 780.net. http://www.kac1780.net/frasier/transcripts/season_11/episode_1/no_sex_please_were_skittish.html. Accessed 20 August 2019.

10. Darowski, Joseph, and Kate Darowski. 2017. Frasier. A cultural history. Lanham, MD: Rowman and Littlefield.

11. Denvir, John. 2000. The lawyer gets the girl—And creates the future. Picturing Justice. https://cappress.com/sites/pj/articles/liberty.htm. Accessed 16 August 2019.

12. Deutsch, Morton. 1971. Equity, equality, and need: What determines which value will be used as the basis of distributive justice? Journal of Social Issues 31(3): 137-149.

13. Durkheim, Emil. 1976. Regeln der soziologischen Methode. 4th edition, ed. René König. Neuwied: Luchterhand.

14. Durkheim, Emil. 1998. Physik der Sitten und des Rechts-Vorlesungen zur Soziologie der Moral (translated by Michael Bischoff). Frankfurt-on-Main: Suhrkamp.

15. Ehrlich, Eugen. 2002. Fundamental principles of the sociology of law (translated by Walter L. Moll). New Brunswick: Transaction.

16. Ehrlich, Eugen. 1967. Das lebende Recht der Völker der Bukowina. In Eugen Ehrlich, Recht und Leben, ed. Manfred Rehbinder, 43-60. Berlin: Duncker \& Humblot.

17. Galanter, Marc. 1998. The faces of mistrust: The image of lawyers in public opinion, jokes, and political discourse. University of Cincinatti Law Review 66: 805-845.

18. Gates, Anita. 1998. Television; Yes, America has a class system. See "Frasier". The New York Times. $\quad$ https://www.nytimes.com/1998/04/19/arts/television-yes-america-has-a-class-system-seefrasier.html. Accessed 17 August 2019.

19. Greenfield, Steve, Guy Osborn, and Peter Robson. 2001. Film and the law. London: Cavendish.

20. Greenfield, Steve, Guy Osborn, and Peter Robson. 2010. Film and the law-The cinema of justice, 2nd ed. Oxford: Hart.

21. Griffith, Eleanor Bley. 2019. Kelsey Grammer reveals first details of his Frasier sequel - and Frasier's change of profession. Radio Times. https://www.radiotimes.com/news/tv/2019-02-13/kelse y-grammer-frasier-sequel-reboot/. Accessed 16 August 2019.

22. Hornby, Richard. 2015. Sitcom. The Hudson Review 68: 111-117.

23. Internet Movie Database. n.d. Crane vs. Crane. Plot. https://www.imdb.com/title/tt0582366/plots ummary?ref_=tt_ov_pl. Accessed 17 August 2019.

24. Keenan, Joe. 1999. The ski lodge. In The best of Frasier, 255-275. London: Channel 4 Books.

25. Lambert, John R. 1970. Crime, police and race relations. A study in Birmingham. London: Oxford University Press.

26. Lloyd, David. 1994. You can't tell a crook by his cover (transcribed by John Masson). KACL 780 . net. http://www.kac1780.net/frasier/transcripts/season_1/episode_15/you_cant_tell_a_crook_by_ his_cover.html. Accessed 17 August 2019.

27. Lloyd, David. 1996. Crane vs. Crane (transcribed by Andrea Day). KACL 780.net. http://www.kacl7 80.net/frasier/transcripts/season_3/episode_19/crane_vs_crane.html. Accessed 17 August 2019.

28. Lloyd, David. 2001. Forgotten but not gone (transcribed by Mike Lee). KACL 780.net. http://www. kac1780.net/frasier/transcripts/season_8/episode_18/forgotten_but_not_gone.html. Accessed 16 September 2019.

29. Lombroso Ferrero, Gina. 1911. The criminal man. According to the classification of Cesare Lombroso. London: G. P. Putnam's Sons.

30. Lorenz, Aaron R.S. 2014. The state of nature and laws of Seinfeld: Not that there's anything wrong with that. International Journal of the Semiotics of Law 27(1): 65-84.

31. Luhmann, Niklas. 1985. A sociological theory of law, ed. Martin Albrow (translated by Elizabeth King and Martin Albrow). London: Routledge and Kegan Paul. 
32. Luhmann, Niklas. 2000. The reality of the mass media. Stanford, CA: Stanford University Press.

33. Macauley, Stewart. 1987. Images of law in everyday life: The lessons of school, entertainment and spectator sports. Law and Society Review 21: 185-218.

34. Machura, Stefan. 2005. Procedural unfairness in real and film trials: Why do audiences understand stories placed in foreign legal systems? In Law and popular culture, ed. Michael Freeman, 148-159. Oxford: Oxford University Press.

35. Machura, Stefan. 2018. Representations of law, rights and criminal justice. In Oxford encyclopedia of crime, media, and popular culture, ed. Nicole Rafter, Michelle Brown, Katherine Biber, Eamonn Carrabine, Gray Cavender, Stefan Machura and Judah Schept, 190-208. New York: Oxford University Press. https://doi.org/10.1093/acrefore/9780190264079.013.201. Accessed 16 August 2019.

36. Machura, Stefan, and Michael Böhnke. 2018. The legal system in German popular culture. In Oxford encyclopedia of crime, media, and popular culture, ed. Nicole Rafter, Michelle Brown, Katherine Biber, Eamonn Carrabine, Gray Cavender, Stefan Machura and Judah Schept, 451-468. New York: Oxford University Press.

37. Machura, Stefan, and Llewelyn Davies. 2013. "Law is an odd thing"-Liberalism and law in the tvseries "The Good Wife". Kriminologisches Journal 45: 279-294.

38. Machura, Stefan, Thomas Love, and Adam Dwight. 2014. Law students' trust in the courts and the police. International Journal of Law, Crime and Justice 42: 287-305.

39. Machura, Stefan, and Stefan Ulbrich. 2001. Globalizing the Hollywood courtroom drama. Journal of Law and Society 28: 117-132.

40. Mead, George Herbert. 1980. Psychologie der Strafustiz. In Gesammelte Aufsätze, Vol. 1, ed. Hans Joas, 262-263: Frankfurt-on-Main: Suhrkamp.

41. Morrissey, Daniel J. 1995. The catholic moment in legal education. Marquette Law Review 78: 413-425.

42. Papke, David Ray. 2018. American lawyer and courtroom comedies. In Oxford encyclopedia of crime, media, and popular culture, ed. Nicole Rafter, Michelle Brown, Katherine Biber, Eamonn Carrabine, Gray Cavender, Stefan Machura, and Judah Schept, 10-22. New York: Oxford University Press.

43. Parson, Talcott. 1971. Recht und soziale Kontrolle. In Materialien zur Rechtssoziologie. Kölner Zeitschrift für Soziologie und Sozialpsychologie, special issue no. 11, 2nd edition, ed. Ernst E. Hirsch und Manfred Rehbinder, 121-134. Opladen: Westdeutscher Verlag.

44. Perlman, Heide. 2003. Door jam. KACL 780.net. http://www.kac1780.net/frasier/transcripts/seaso n_10/episode_11/door_jam.html. Accessed 16 August 2019.

45. Petrazycki, Leon. 2011. Law and morality, ed. A. Javier Treviño. New Brunswick: Transaction Publishers.

46. Plett-Giordano, Anne, and Chuck Ranberg. 1999. A midwinter night's dream. In: The best of Frasier, 40-58. London: Channel 4 Books.

47. Podlas, Kimberlianne. 2007. Homerus lex: Investigating American legal culture through the lens of The Simpsons. Seton Hall University School of Law Journal of Sports and Entertainment Law 17: 93-134.

48. Porsdam, Helle. 1999. Legally speaking. Contemporary American culture and the law. Amherst, MA: University of Massachusetts Press.

49. Rafter, Nicole. 2006. Shots in the Mirror. Crime films and society, 2nd ed. Oxford: Oxford University Press.

50. Rapping, Elayne. 2003. Law and justice as seen on tv. New York: New York University Press.

51. Robson, Peter. 2014. The law through the eye of courtroom comedy: The light legal procedural in context. In: Law and popular culture. International perspectives, ed. Michael Asimow, Kathryn Brown and David Ray Papke, 233-249. Newcastle on Tyne: Cambridge Scholars Publishing.

52. Robson, Peter. 2019. Developments in revenge, justice and rape in the cinema. International Journal of the Semiotics of Law. https://doi.org/10.1007/s11196-019-09614-7.

53. Sennett, Richard. 1983. Verfall und Ende des öffentlichen Lebens: Die Tyrannei der Intimität (translated by Reinhard Kaiser). Frankfurt-on-Main: Fischer.

54. Shaw, Julia J.A. 2018. From Beethoven to Bowie: Identity framing, social justice and the sound of law. International Journal of the Semiotics of Law 31(2): 301-324.

55. Sherwin, Richard K. 2000. When the law goes pop. The vanishing line between law and popular culture. Chicago: University of Chicago Press.

56. Smethurst, William. 2009. A guide to writing and selling successful TV scripts. Oxford: How To Books. 
57. Toobin, Jeffrey. 1996. The run of his life. The People vs. O. J. Simpson. New York: Random House.

58. Tyler, Tom R., Phillip Atiba Goff, and Robert J. MacCoun. 2015. The impact of psychological science on policing in the United States: Procedural justice, legitimacy, and effective law enforcement. Psychological Science in the Public Interest 16(3): 75-109.

59. Vidmar, Neil. 1997. Medical malpractice and the American jury. Confronting the myths about jury incompetence, deep pockets, and outrageous damage awards. Michigan: University of Michigan Press.

60. Weber, Bruce. 2009. David Lloyd, 75, Dies; Wrote 'Chuckles' episode. New York Times. https:// www.nytimes.com/2009/11/13/arts/television/13lloyd.html. Accessed 17 August 2019.

61. Weber, Max. 1968. Economy and society, ed. Guenther Roth and Claus Wittich. New York: Bedminster Press.

62. Wolff, Leon. 2019. Laughing at the law. A socio-semiotic analysis of legal comedy on Japanese prime-time television. International Journal of the Semiotics of Law. https://doi.org/10.1007/s1119 6-019-09649-w.

63. Zicklin, Eric, and Lori Kirkland. 2001. A day in May (transcribed by Mike Lee). KACL 780.net. http://www.kacl780.net/frasier/transcripts/season_8/episode_23/a_day_in_may.html. Accessed 17 Aug 2019.

Publisher's Note Springer Nature remains neutral with regard to jurisdictional claims in published maps and institutional affiliations. 